\title{
Issue of Consent as a Defence of Deliberate Killing in English Law
}

\author{
Ingiliz Hukukunda Kasten Öldürmede Ceza Sorumluluğunu Kaldıran \\ veya Azaltan Bir Neden Olarak Rvza Sorunu
}

\section{Z. Özlem ERSOY YILMAZ ${ }^{1}$}

${ }^{1}$ Res. Asst., Ondokuz Mayıs University, Samsun, Turkey

\section{ABSTRACT}

In this article, the issue of whether consent should provide a complete or a partial defence of deliberate killing will be challenged within the scope of English law. In order to answer this, the article first determines what makes consent of the victim powerless in current English law. Next, the following topics will be addressed. First, what consent means and what the legal and moral effects of it are. Second, the reasons behind the current law for not recognizing consent as a defence of deliberate killing. Finally, this paper discusses whether or not consent should serve as a defence of deliberate killing. Although it may be claimed that consent reduces the wrongfulness of the act, it will be argued that consent alone should never provide a defence for those who deliberately kill others, due to an objective moral reasoning, namely human dignity.

Keywords: Deliberate killing, defence, consent

Öz

Bu makalede, İngiliz hukukunda kasten öldürme suçunda rızanın ceza sorumluluğunu kaldıran veya azaltan bir neden olarak kabul edilip edilmemesi sorunu ele alınacaktır. Bunu cevaplamak için öncelikle günümüzde İngiliz hukukunda kasten öldürmede mağdurun rızasını neyin etkisiz bıraktığı belirlenecektir. Daha sonra aşağıdaki konulara değinilecektir; ilk olarak, rıza nedir ve rızanın yasal ve ahlaki etkileri nelerdir, ikinci olarak, uygulanan hukukun rızayı kasten öldürmede ceza sorumluluğunu kaldıran bir neden olarak saymamasının arkasındaki sebepler nelerdir ve son olarak da rızanın kasten öldürmede ceza sorumluluğunu kaldıran bir neden olarak hizmet edip etmemesi gereği tartışılacaktır. Her ne kadar rızanın eylemin haksızığını azalttığı söylenebilirse de insan onuru denilen nesnel ahlaki sebepten ötürü, rızanın tek başına kasten öldürmede hiçbir şekilde ceza sorumluluğunu kaldıran bir neden sayılmaması gerektiği tartışılacaktır. Anahtar Kelimeler: Kasten öldürme, meşru savunma, rıza 


\section{EXTENDED ABSTRACT}

Current criminal law in England and Wales does not recognize consent of the victim as a defence of deliberately killing others. Although in cases of terminal illness patients have the right to deny life-saving treatment or to request pain-killers even in fatal doses, it is an offence to deliberately act to end a person's life in English law. A person's consent does not serve as a defence in these cases of terminal illnesses, let alone killing for gratification. However, the right to consent to pain, injury or death always attracts interest as a result of a number of criminal trials which include consenting victims in a range of activities such as mercy killing, active euthanasia and cannibalism. Hence it is an ongoing debate whether consent or request of a victim should affect the criminal liability of the perpetrator, either by diminishing liability completely or by decreasing the degree of it.

Historically, before the seventeenth century the "volenti non fit injuria (a person is not wronged by that to which she consents)' maxim was valid, and so individuals were free to consent to almost anything. With the change in the system of punishment towards monopolization, the victim was no longer the central figure in the normative and centralised judicial structure. Inevitably, historically private offences turned into the public offences. As a result, consent of the victim lost its power in certain criminal acts which the state considers as damaging to itself. In this conventional conception of consent, when a perpetrator breaches the law she threatens the head of the state to define and guarantee the citizens' rights. Currently, although there is a meaningful distinction between both consensual acts of mercy killing and killing for gratification, still as a matter of public policy, no one can consent to her own death.

Putting paternalistic and subjective moral reasons such as the state or the public's interest in prohibiting its citizens from harming themselves aside, as they may extend the scope of criminal law to an undesired level, an objective moral reason, namely 'human dignity' as in the Kant's second formulation of the Categorical Imperative, can be argued to constitute a strong foundation for limiting personal autonomy. Dignity is an essential characteristic of all human beings, therefore a degrading conduct might be wrongful even if it does not violate the victim's rights due to consent. In this respect, consent as an exercise of personal autonomy remains valid until the act crosses the boundaries of degrading human dignity to a serious degree. When the consenter's dignity is violated, meaning when she is treated as a mere means to her end rather than as end in itself, consent loses its power as a justifying 
reason. From this point of view, confirming that harm is not only a violation of rights but also the violation of human dignity leads us to conclude that consent should always be at least partial defence, since it negates one part of harm, namely violation of rights. In this respect, considering active euthanasia or mercy killing as an act of respecting ones' dignity and also not a violation of a person's rights, these kinds of acts along with other strict conditions should not be subject to criminal liability at all. It can be said that even in these circumstances of respect, consent alone cannot serve as a defence for deliberate killing, therefore consent to being killed just for gratification should neither provide complete nor partial defence.

English law embraces consent fully when absence of consent is an intrinsic and essential element of the offence, as in the example of rape, kidnapping or theft. However, for other offences involving physical harm, consent plays the role of defence only for limited number of cases, such as, actual bodily harm, lawful sports and medical treatment. Although legally and morally there is some difference between killing for mercy or active euthanasia (which is legal in some countries, but under strict conditions) and killing for gratification, in both cases consent by itself does not constitute a defence for criminal liability. However, consent not only represents a defence but is also a part of personal autonomy which is one of the foundations of the modern state. Therefore, there needs to be more explanation than bare legal prohibitions for not being able to consent for acts concerning one's own body.

\section{Introduction}

Current criminal law in England and Wales does not recognize the consent of the victim as a defence of deliberately killing others. Under English law, even suicide was a criminal act until 1961. The Suicide Act of 1961, while declaring suicide to no longer be punishable, decreed that aiding, abetting or encouraging another person's suicide is subject to up to 14 years imprisonment. ${ }^{1}$ However, even if it hastens the death of a terminally-ill patient, it is legal to administer fatal doses of pain-killers as long as the purpose remains to relieve the pain and not to end the patient's life. By way of example, Dr. Moor was acquitted from the murder charge of his 85 year old terminally ill cancer patient after giving him a dose of diamorphine. ${ }^{2}$ Additionally, patients have the right to refuse life-saving treatment whether it could lead to death

\footnotetext{
$1 \quad$ Suicide Act 1961, ss 1 and 2.

2 'Dr Moor: Landmark Verdict' (BBC News, 28 November 2000) <http://news.bbc.co.uk/1/hi/health/ background_briefings/euthanasia/331263.stm> accessed 7 February 2018.
} 
or not, and doctors have to respect that request. ${ }^{3}$ For instance, Mary Ormerod weighed less than four stone (around $25 \mathrm{~kg}$ ) when she died as a result of the withholding of her nutritional supplement with the permission of her daughters. ${ }^{4}$ Although this is the current view of English law, it is also valid for the USA and most other western countries. ${ }^{5}$ Another type of killing on demand arose with the sensational German case of Armin Meiwes, who was sentenced to life in prison for murder, despite the fact that to be killed was the victim's wish. ${ }^{6}$ These cases of deliberate killings do not require any health problems and are generally for the pure gratification of the killer and appear where the victim has either requested to be killed or consented to be killed. Hence it can be said that although deliberate killing means killing someone knowingly and willingly, it needs to be asked whether the motivation of killing under other conditions should affect the validity of consent. Therefore, it is an ongoing debate whether consent or request of a victim should affect the criminal liability of the perpetrator, either by diminishing liability completely or by decreasing the degree of it. ${ }^{7}$

As can be understood from this short introduction, the issue of whether consent should provide a complete or a partial defence of deliberate killing, either for motivations of mercy or gratification, needs to be further evaluated. In the following pages it will first be determined what makes consent of the victim powerless in current English law. In order to answer this question, what consent means and what the legal and moral effects of it are needed to be addressed first. Later, the reasons behind current English law for not recognizing consent as a defence of deliberate killing will be identified, and finally, whether or not consent should serve as a defence of deliberate killing will be questioned. Although it may be claimed that consent reduces the wrongfulness of the act, it will be argued that consent alone should never provide a defence for those who deliberately kill others when it undermines human dignity.

3 See Nigel Biggar, Aiming to Kill: The Ethics of Suicide and Euthanasia (Darton, Longman and Todd 2004).

4 'Whose Decision Is It Anyway?' (BBC News, 28 November 2000) <http://news.bbc.co.uk/1/hi/health/ background briefings/euthanasia/331268.stm> accessed 7 February 2018.

5 See John Keown, Euthanasia, Ethics and Public Policy: An Argument Against Legalisation (Cambridge University Press 2002).

6 The Associated Press, 'German Court Sentences Cannibal to Life in Jail' (World News, 5 September 2006) $<$ http://www.nbcnews.com/id/11909486/ns/world_news/t/german-court-sentences-cannibal-life-jail/\#. WwKhXC_BLu0> accessed 7 February 2018.

7 See Roger Leng, ‘Consent in Criminal Law' (1988) 13 Holdsworth Law Review 129. 


\section{The Meaning of Consent and Its Legal and Moral Effects}

The right to consent to pain, injury or death always attracts the interest of authors from criminal law and moral philosophy fields. As a result of a number of criminal trials which include consenting victims in a range of activities from mercy killing to cannibalism, such as those mentioned above, the notion of consent and its effects have gained attention from the public, as well as from academics and legislators, thus raising the profile of this issue. In the following subsections, historical and current conceptions of consent as well as how it is exercised and the legal and moral effects of it will be addressed.

\subsection{The Historical Conception of Consent}

Common law considers deliberately injuring or killing someone as wrong. This presumption of wrong might be overruled by the perpetrator's defence of justification, and the consent of the victim would provide such a defence, yet traditionally, English law does not accept the defence of consent on homicide charges. This special rule of consent to physical harm historically derives from Anglo-American jurisprudence in the seventeenth century. Before that, the 'volenti non fit injuria (a person is not wronged by that to which she consents)' maxim was valid, which was a private law principle in Roman law in the early sixth century and, hence, individuals were free to consent to almost anything. As a result, this was used to prevent the perpetrator from prosecution. ${ }^{8}$ With the change in the system of punishment towards monopolization, the victim was no longer the central figure in the normative and centralised judicial structure. Instead of the violation of the victim's interest, disorder in society became the new interpretation of crime. Inevitably, historically private offences turned into the public offences. The state became the only victim and the prosecutor of the crime. As a result, consent of the victim lost its power in certain criminal acts which the state considered as harm to itself. In this conventional conception of consent, the state is assumed to be the only victim of a violation of the criminal law and when a perpetrator violates the law she threatens the head of state to define and guarantee the citizens' rights. ${ }^{9}$

8 Vera Bergelson, 'The Right to Be Hurt: Testing the Boundaries of Consent' (2007) 75 George Washington Law Review 165, 171-173.

9 Vera Bergelson, 'Consent to Harm' (2008) 28 Pace Law Review 683, 686-688; See also Keith M. Harrison, 'Law, Order, and the Consent Defense' (1993) 12 St. Louis University Public Law Review 477, 478-482. 


\subsection{The Current Conception of Consent}

Today, similarly, although there is a meaningful distinction between deliberate killing for gratification and mercy, still as a matter of public policy, no one can consent to her own death. At the present time, English law embraces a number of offences that can only be committed if there is a lack of consent of a certain person to a certain conduct or a certain consequence. The reason for this is that these offences include some interference with the personal right of the individual and generally a person has the liberty to waive her rights; consent hereby nullifies the harm in these cases. Some may claim that these offences are examples of consent providing a defence. However, considering the technical and more limited description of the defence as a factor which will cancel out liability even though the positive elements of the offence are proved, the absence of consent constitutes an intrinsic element of the offence here. Hence, it cannot be seen as a defence. ${ }^{10}$ On the one hand, the role of consent in offences such as, rape, kidnapping or theft, can be described as inculpatory, but in other cases, by defeating the prima facie harm, consent removes the possibility of an offence. On the other hand, in cases involving physical harm, the role of consent becomes exculpatory, because even it is morally and legally excused, consensual bodily harm or death still remain harmful. ${ }^{11}$

In order to explain the role of consent in detail, George Fletcher determines that, for common law countries, inculpatory and exculpatory functions of an element demonstrate the distinction between a duty to obey, a prohibitory legal norm and a right to violate it when justificatory circumstances exist. He gives the offence of reckless driving as an example to exhibit that while it is unimaginable to ban driving at all, reckless driving can be banned. In this case, 'recklessly' is an element of the definition of the offence, not a defence. ${ }^{12}$ Briefly, consent may be considered as a defence only when the act itself violates a prohibitory norm. Having intercourse with someone or entering someone's home does not violate a prohibitory norm if consent is present. By contrast, killing or injuring an individual are by themselves morally bad activities. Even though a defence may justify them, it cannot make them morally neutral. ${ }^{13}$

10 Leng (n 7) 129.

11 Bergelson, 'The Right to Be Hurt' (n 8); Bergelson, 'Consent to Harm' (n 9).

12 George P. Fletcher, Rethinking Criminal Law (Oxford University Press 2000) 566-568.

13 Bergelson, 'The Right to Be Hurt' (n 8) 203. 


\subsection{Exercise of Consent as a Defence}

As explained above, consent provides a defence only with regards to offences that preserve certain personal rights that might be waived. Except for the offences in which the lack of consent has to be proved by the state as an element of the offence, customarily consent has been completely irrelevant for offences such as homicide. The reason for this is, as stated above, in homicide and bodily injury cases, a lack of consent of the victim is not a necessary element of the offence. It is the rule that an individual's consent does not diminish the criminal liability of a perpetrator for a forbidden act. ${ }^{14}$

In common criminal law, only within three circumstances does the consent of the victim excuse the perpetrator for inflicting bodily harm: first, if the injury is trivial; second, if the injury occurred as a reasonably foreseeable harm while participating in a lawful activity or in an activity that is not forbidden by the law; and last, if the bodily harm was inflicted as an accepted form of treatment. ${ }^{15}$ In short, you are not allowed to consent to harm unless your activities are on the list of things approved by the state. ${ }^{16}$ Other than a few cases such as horseplay ${ }^{17}$, reasonable surgical interference, cosmetic enhancements, tattooing, piercing ${ }^{18}$, properly supervised games and sports ${ }^{19}$, one cannot consent to an injury of the level of actual or grievous bodily harm or to be murdered. Also, the House of Lords and the European Court of Human Rights stated that no one can consent to injury beyond actual bodily harm, and to those few circumstances that are mentioned above, even in private and between adults. ${ }^{20}$

14 Harrison (n 9) 479; Joseph Henry Beale, 'Consent in the Criminal Law' (1894-1895) 8 Harvard Law Review 317, 324-325.

15 Model Penal Code (1985) s 2.11.

16 Bergelson, 'Consent to Harm' (n 9) 687; Offences Against the Person Act 1861, s 47; A-G ref No 6 of 1980 [1981] QB 715.

$17 \quad R$ v Jones [1987] Crim LR 123 (CA).

$18 \quad R v$ Wilson [1996] Crim LR 573 (CA).

$19 R v$ Coney (1882) 8 QBD 534, Judge Stephens: 'When one person is indicted for inflicting personal injury upon another, the consent of the person who sustains the injury is no defence to the person who inflicts the injury, if the injury is of such a nature, or is inflicted under such circumstances, that its infliction is injurious to the public as well as to the person injured. But the injuries given and received in prize-fights are injurious to the public, both because it is against the public interest that the lives and the health of the combatants should be endangered by blows, and because prize-fights are disorderly exhibitions, mischievous on many obvious grounds. Therefore the consent of the parties to the blows which they mutually receive does not prevent those blows from being assaults.'

$20 R$ v Brown [1994] 1 AC 212 (HL); Laskey, Jaggard, and Brown v The United Kingdom [1997] Case No.109/1995/615/703-705. 
To be valid, consent has to be positive and genuine, meaning it must be different from just a submission and not be vitiated by fraud, mistake, force, threats and abuse of power. In addition, the nature of the act must be comprehended. Furthermore, particular groups of people such as children, the mentally ill and intoxicated persons cannot give valid consent. ${ }^{21}$ In respect to American penal law, Vera Bergelson, who is an American author, divides the consent defence into two types: complete and partial defence. To provide complete defence, a victim's rational and voluntary consent for the injurious act, needs to be subjectively compassionate and the perpetrator's act must generate an overall positive balance of harm and evils, including the victim's personal interests and dignity. She believes that otherwise the rational and voluntary consent should be accepted as a partial defence, as it lessens the wrongfulness of the conduct. ${ }^{22}$

\subsection{Legal and Moral Effects of Consent}

Taking into consideration that conventionally criminal harm is known as wrongful interference with the victim's interest, since consent waives the victim's rights, it can be said that the perpetrator who kills or injures based on consent does not violate the victim's rights. Nevertheless, despite the fact that neither rape nor kidnapping are less serious offences than assault, while consent of the victim converts them into a legal activity, it cannot change either the legal or the moral nature of assault. ${ }^{23}$

According to Heidi Hurd, through our rights and others' obligations, significant limits are generated to exercise the right of liberty for others. Nevertheless, by making promises we create obligations for ourselves. In addition, by authorizing and withdrawing consent we constitute rights for others. ${ }^{24}$ She describes that consent can morally change another person's deed in two different ways, namely by 'moral transformative' and 'stained permission'. In the former way, consent makes the conduct right while it would otherwise be wrong. Take the example of theft which turns into a gift when the consent element is present. In the latter way, even though consent does not morally turn a wrong deed into a right one, it permits another person to commit a wrong act. This second function of consent becomes ineffective for the actions that are forbidden by the law. ${ }^{25}$

21 Burrell v Harmer [1967] Crim LR 169; Gillick v West Norfolk \& Wisbeck Area Health Authority [1986] AC $112 \mathrm{HL}$.

22 Bergelson, 'Consent to Harm' (n 9) 701-711.

23 Ibid 703.

24 Heidi M. Hurd, 'The Moral Magic of Consent' (1996) 2 Legal Theory 121, 123.

25 Ibid. 
An important consequence of distinguishing the role of consent is if the consent is an element of an offence, the full burden of proof will rest with the prosecution. Moreover, if consent is in the definition of the charged offence, since the presence of consent nullifies the defendant's mens rea, there will be no conviction. Thus, when consent plays an inculpatory role, it generates a better situation for the defendant. In short, it is important to identify the role of consent in order to examine its effects. ${ }^{26}$

\section{Reasons Behind Current English Law for Not Recognizing Consent as a Defence of Deliberate Killing}

Having considered the current state of the law of consent, it is time to clarify the reasons for not allowing consent to serve as a defence of deliberate killing. There are a wide range of theories from religious to moral, from paternalistic to liberal, which are used to rationalise limiting one of the most important values that a free democratic society is built upon, namely personal autonomy.

In moral philosophy, the ability to consent reflects individual autonomy. It is believed that 'the capacity for autonomy is the capacity for self-legislation.' ${ }^{27}$ In other words, 'consent is intimately related to the capacity for autonomous action; one who cannot alter others' obligations through consent is not fully autonomous.' ${ }^{28}$ In a similar vein, modern political theory associates the legitimacy of the state with the consent of its citizens. ${ }^{29}$ From a Millian liberal point of view, a person's liberty can only be limited if her act is intended to cause harm to others. ${ }^{30}$ Neither immorality of the act nor the harm to self is sufficient to limit one's liberty. ${ }^{31}$

In contrast, others may state that the public's interest in the safety of its citizens and the tendency of injurious acts to breach the peace or to cause severe bodily harm are the rationales behind invalidating consent to bodily harm. ${ }^{32}$ Criminal courts also share the view that the state has an interest in prohibiting its citizens, who have capacity to be productive for society, from harming themselves. Another argument on behalf of the state interest in self-regarding the decisions of its citizens is the risk that

26 Bergelson, 'Consent to Harm' (n 9) 696.

27 Hurd (n 24) 123.

28 Larry Alexander, 'The Moral Magic of Consent (II)' (1996) 2 Legal Theory 165, 165.

29 See Markus Dirk Dubber, 'Toward a Constitutional Law of Crime and Punishment' (2004) 55 Hastings Law Journal 507.

30 John Stuart Mill, On Liberty ( $2^{\text {nd }}$ edn, J. W. Parker and Son 1859).

31 Ronald Dworkin, 'Introduction' in R. Dworkin (ed), The Philosophy of Law (OUP 1977) 1.

32 Beale (n 14) 325. 
these citizens would become a 'public charge'. ${ }^{33}$ Nonetheless, some could find this justification of limiting the individual's rights merely on utilitarian grounds as problematic. It can be claimed that this logic may lead us to prevent the poor from having children or even to the sterilization of intellectually disabled ones against their will. Moreover, it can be argued that such an approach, which gives the state the right to criminalise any conduct merely for not being useful to society, dangerously extends the moral limits of criminal law. For instance, the question of whether we should criminalise possession and distribution of unhealthy food substances to solve obesity related health problems might come to mind as an extreme measure. ${ }^{34}$

Regarding the attitude that the criminal law of England adopts towards consent, a former judge, Lord Devlin, conveys that English law is very concerned about moral principles. He states that subject to certain exceptions inherent in the nature of particular crimes, criminal law has never permitted the consent of the victim to be used as a defence. ${ }^{35}$ He explains the reasons for this view as follows: first, crime constitutes an offence against society. And second, although a killer who acts only upon the consent of the victim may not harm anyone, this nonetheless threatens one of the moral principles upon which society is founded, namely 'the sanctity of human life'. ${ }^{36}$ To support his claims, he concludes that acts such as euthanasia or killing another at his own request, suicide, attempted suicide and suicide pacts, duelling, abortion, and incest are all acts which can be done in private and without offence to others and need not involve the corruption or exploitation of others, yet they were once forbidden by the law. ${ }^{37}$

As well as paternalistic and subjective moral rationales that encroach upon personal autonomy, courts and academics propose various non-paternalistic rationales for invalidating consent to bodily harm. Bergelson divides them in two categories, namely 'harm to self' and 'harm to others'. 'The first theory presumes that the apparent consent was not truly voluntary and rational and, therefore, is invalid. The

33 State v. Bass, 120 S.E. 2d 580, 586 (N.C. 1961); Bergelson, 'The Right to Be Hurt' (n 8) 34.

34 Bergelson, 'The Right to Be Hurt' (n 8) 191.

35 Patrick Devlin, 'Morals and The Criminal Law' in R. Dworkin (ed), The Philosophy of Law (OUP 1977) $66,70-71$.

36 Ibid.

37 Ibid (Suicide pact is a defence in UK by the Homicide Act 1957, s 4; Sam Jones, 'Pensioner Cleared of Killing Wife of 50 Years in Failed Suicide Pact' The Guardian (30 April 2010) <https://www.theguardian. $\mathrm{com} /$ society/2010/apr/30/suicide-pact-not-murder?INTCMP $=\mathrm{SRCH}>$ accessed 7 February 2018, as well as passive euthanasia as mentioned in the introduction, and sexual intercourses between adults in private is not within the scope of UK criminal law.) 
second maintains that, unless the consensual injurious act is prohibited, society will suffer significant harm. ${ }^{38}$

\subsection{Harm to Self}

It is true that in some situations, as in the extreme example of the Meiwes case which is mentioned above, it is hard to believe that the victim was rational while he consented to such harm. Therefore, it might be said that his consent should not be validated. Additionally, although victims are not subject to duress or coercion, it can be thought that they may not be consenting voluntarily. ${ }^{39}$ As Joel Feinberg, an American author, points out, it is questionable whether a severely suffering or depressed person can give a voluntary and rational consent to justify her death or not. ${ }^{40}$ Conversely, Bergelson asserts that although it is disturbing, the truth that mentally competent adults may genuinely wish to be harmed needs to be encountered, after several psychiatric evaluation tests are completed. ${ }^{41}$

\subsection{Harm to Others}

Feinberg suggests an autonomy-respecting argument which could still tolerate the state's interference with its citizens' private decisions. ${ }^{42}$ He underlines that society has to intervene for the sake of others who will have to carry the burden of economic cost and misery thereafter. He concludes that '...it is not the individual whom the state paternalistically seeks to protect from his own unwise decisions; it is rather society at large who will suffer if the individual is permitted to act as he wishes. ${ }^{23}$ Furthermore, the empirical form of 'slippery slope' arguments, which Feinberg describes as part of a 'falling dominoes', implies that allowing people to consent to be harmed would eventually lead to a significant harm to society. ${ }^{44}$ In parallel with this, Roger Leng considers that acknowledging the consent to be a complete or partial defence to homicide would lead to direct or indirect pressure on elderly, infirm and handicapped persons to request or consent to be killed, a point which should be highly considered. ${ }^{45}$

38 Bergelson, 'The Right to Be Hurt' (n 8) 185.

39 Ibid.

40 Joel Feinberg, The Moral Limits of The Criminal Law: Harm to Self, vol 3 (OUP 1986) 345.

41 Bergelson, 'The Right to Be Hurt' (n 8) 186.

42 Feinberg (n 40) 345.

43 Ibid.

44 Ibid.

45 Leng (n 7) 136. 
On the contrary, Bergelson underlines that to avoid loopholes, higher proof of rationality and voluntariness of the consent should be requested by the law, rather than taking away the right to consent altogether. Courts have the right to request sound evidence of the victim's consent, but the risk of abuse should not be the foundation of a rule banning consensual harm altogether. ${ }^{46}$ It should be noted that the possibility of abuse and mistake is not a sufficient and conclusive reason to forbid consensual deliberate killing. Although the possibility of abuse and mistake is relevant to the issue, the risk of exploitation of the norm is just another point to consider regarding providing reliable legal institutions and effective safeguards. ${ }^{47}$ In short, there is need for morally and conceptually more coherent rationales that focus on the victim's interest and the perpetrator's reasons for the harmful act. ${ }^{48}$

\section{Views on Consent as a Defence of Deliberate Killing}

In order to plausibly answer the question whether consent should provide a defence of deliberately killing others or not, it is also necessary to consider the recent arguments on the issue.

\subsection{Consent is Limited}

In relation to the issue of consent, Dennis Baker emphasizes the distinction between waiving rights as exercising personal autonomy and waiving rights as violating rational autonomy and a person's human dignity. He suggests the implication of Kant's second formulation of the Categorical Imperative as a moral limit to consent. He states that although, in general, consent justifies wrongful harmdoing to others, it can be objectively limited by other objective notions of greater significance. Consent nullifies offence only if the act causes actual bodily harm or when lack of consent is an intrinsic and essential element of the offence, consent is not absolute under English law. Even though the notion of consent preserves personal autonomy, it does not allow one to degrade or destroy the consenting party's human dignity. An individual can forfeit or alienate her personal autonomy whereas she cannot alienate her rational autonomy. Until the harm crosses the boundaries of degrading human dignity to a serious degree, consent as an exercise of personal autonomy remains valid. When the consenter's dignity is violated, meaning when she is treated as a

46 Bergelson, 'The Right to Be Hurt' (n 8) 188.

47 Yale Kamisar, 'Some Non-Religious Views against Proposed Mercy Killing Legislation' (1958) 42 Minnesota Law Review 969, 976. 
mere means to her end rather than as end in itself, it is hard to recognize consent as a justifying reason. ${ }^{49}$ Similarly, it can also be stated that the right to be respected as a rational being is cardinal and cannot be waived. ${ }^{50}$

\subsection{Considering Consent as a Partial Defence}

It is widely accepted that dignity is essential to our humanity. Human dignity can be defined as '....an expressive value demanding that people's behaviour, physical and verbal, convey a certain attitude to other people, namely an attitude of respect. ${ }^{51}$ Moral dignity is an essential characteristic of all human beings therefore a degrading conduct might be wrongful even if it does not violate the victim's rights. The recent concept of criminal harm is not only restricted to a violation of the victim's autonomy, but also involves the violation of the victim's dignity. ${ }^{52}$ It would not be wrong to propose that regarding consensual physical harm, as in the Meiwes case, it was not the victim's right to life that was violated since the victim consented to be killed and eaten, but the victim's dignity was violated as his equal moral worth was denied. Hence, consensual killing to experience cannibalism and similar activities should certainly be punishable. However, confirming that harm is not only a violation of rights but also the violation of human dignity, leads us to conclude that consent should always be at least partial defence, since it negates one part of harm, namely violation of rights. It should be considered that a consensual but degrading act is less wrongful than an identical non-consensual act. ${ }^{53}$

For instance, the German Criminal Code, section 216 regulates a special offence called 'killing at the request of the victim; mercy killing' ${ }^{54}$, which should not be confused with voluntarily active euthanasia as it does not require an illness. As a result of the killing's wrongfulness is diminished by the consent, section 216 provides lesser sentences than for other types of homicide. ${ }^{55}$ Some may claim that even though a mercy killing of a suffering, terminally ill patient violates the patient's interest in

49 Dennis J. Baker, 'The Moral Limits of Consent as a Defense in the Criminal Law' (2009) 12 New Criminal Law Review 93, 112.

50 Thomas Hill, Autonomy and Self-Respect (Cambridge University Press 1991) 15-16.

51 Mehir Dan-Cohen, 'Basic Values and the Victim's State of Mind' (2000) 88 California Law Review 759, 771.

52 Dubber (n 29) 515; R. Antony Duff, 'Harms and Wrongs' (2001) 5 Buffalo Criminal Law Review 13.

53 Bergelson, 'The Right to Be Hurt' (n 8) 170; Bergelson, 'Consent To Harm' (n 9) 708.

54 Similar regulation takes place in the Criminal Code of the Republic of Austria 1974 (amended 2015), article 77 .

55 Fletcher (n 12) 332. 
living, however, when warranted by the patient's condition and motivated by compassion, such killing respects and preserves the dignity of the dying individual, and, therefore, should not be subject to criminal liability at all. ${ }^{56}$

\subsection{Difference between Deliberate Killings}

The recent concept of criminal harm with regards to consent guides us to separate killing as against human dignity from killing for mercy. It can be argued that euthanasia involves a humanitarian motive which distinguishes it from merely killing. Some further argue that, in euthanasia cases, forcing one to stay alive against her will rather than helping her death can be seen degrading. 'Human dignity is not possible without the acknowledgement of personal sovereignty. ${ }^{57}$ Many may see voluntary active euthanasia as shortening the patients' lives, even though patients consider it better off for them. Hence, Ronald Dworkin argues that 'Making someone die in a way that others approve, but he believes a horrifying contradiction of his life, is a devastating, odious form of tyranny'. ${ }^{58}$ However, no one suggests that consensual cannibalistic or similar activities which include deliberate killing for gratification should completely be kept out of criminal law.

Having evaluated these arguments on consent above, it can be said that validity of a consent ends when the consented act crosses the boundaries of human dignity. Dignity is an essential characteristic of all human beings, therefore a degrading conduct might be wrongful even if it does not violate the victim's rights due to consent. In this respect, consent as an exercise of personal autonomy remains valid until the act crosses the boundaries of degrading human dignity to a serious degree. When the consenter's dignity is violated, meaning when she is treated as a mere means to her end rather than as end in itself, consent loses its power as a justifying reason. From this point of view, confirming that harm is not only a violation of rights but also the violation of human dignity, leads us to the conclusion that consent should always be at least partial defence, since it negates one part of harm, namely violation of rights. In this respect, considering consensual active euthanasia or mercy killing as an act of respecting ones' dignity and also not a violation of her rights, such consensual acts along with other strict conditions should not be subject to criminal liability at all. It can be said that even in these

56 Bergelson, 'Consent To Harm' (n 9) 707.

57 Feinberg (n 40) 354.

58 Ronald Dworkin, Life's Dominion: An Argument about Abortion and Euthanasia (Harper Collins Publishers 1993) 217; Keown (n 5) 52-53. 
circumstances of respect, consent alone cannot serve as a defence for deliberate killing, there are other requirements such as an illness, therefore consent to being killed just for gratification should neither provide complete nor partial defence..$^{59}$

\section{Conclusion}

In summary, it can be understood that English law embraces consent fully when absence of consent is an intrinsic and essential element of the offence, as in the example of rape or trespassing. However, for other physically harmful offences, consent plays the role of defence only for a limited number of cases, such as, actual bodily harm, lawful sports and medical treatment, whether in private or not. Although there are some moral and legal differences between killing for mercy and killing for gratification, in both cases consent by itself does not constitute a defence for criminal liability. However, consent does not represent only a defence but also constitutes a part of personal autonomy which is one of the foundations of modern state. Therefore, bare legal prohibitions are not regarded as sufficient to explain the reasons behind not being able to consent for acts concerning one's own body. Yet, in this paper, the perception of consent and its limits and impacts has been demonstrated from a different point of view. Considering paternalistic and subjective moral reasons such as state or public's interest in prohibiting its citizens from harming themselves aside as it may extend the scope of criminal law to an undesirable level, an objective moral reason 'human dignity' as in the Kant's second formulation of the Categorical Imperative has been argued to constitute a strong foundation for limiting personal autonomy. Accordingly, the questions of one's voluntariness or rationality for consenting to being killed and the effects of it which may occur on vulnerable individuals can also be overcame by strict regulations. Dignity is an essential characteristic of all human beings, therefore a degrading conduct might be wrongful even if it does not violate the victim's rights due to consent. In this respect, it has been stressed that consent as an exercise of personal autonomy remains valid until the act crosses the boundaries of degrading human dignity to a serious degree. When the consenter's dignity is violated, meaning when she is treated as a mere means to her end rather than as end in itself, consent loses its power as a justifying reason. In the light of given considerations, although it may be acknowledged that consent reduces the wrongfulness of the act to a certain degree, consent alone should never provide a defence for those who deliberately kill others. 


\section{Bibliography}

Alexander L, ‘The Moral Magic of Consent (II)’ (1996) 2 Legal Theory 165.

Baker D J, 'The Moral Limits of Consent as a Defense in the Criminal Law' (2009) 12 New Criminal Law Review 93.

Beale J H, 'Consent In The Criminal Law' (1895) 8:6 Harvard Law Review 317.

Bergelson V, 'The Right to Be Hurt: Testing the Boundaries of Consent' (2007) 75 George Washington Law Review 165.

- - 'Consent to Harm' (2008) 28 Pace Law Review 683.

Biggar N, Aiming to Kill: The Ethics of Suicide and Euthanasia (Darton, Longman and Todd 2004).

Dan-Cohen M, 'Basic Values and the Victim's State of Mind' (2000) 88 California Law Review 759.

Devlin P, 'Morals and The Criminal Law' in R. Dworkin (ed), The Philosophy of Law (OUP 1977) 66.

Dubber M D, 'Toward a Constitutional Law of Crime and Punishment' (2004) 55 Hastings Law Journal 507.

Duff A, 'Harms and Wrongs' (2001) 5 Buffalo Criminal Law Review 13.

Dworkin R, 'Introduction' in R. Dworkin (ed), The Philosophy of Law (OUP 1977) 1.

- - Life's Dominion: An Argument about Abortion and Euthanasia (Harper Collins Publishers 1993).

Feinberg J, The Moral Limits of The Criminal Law: Harm to Self, vol 3 (OUP 1989).

Fletcher G P, Rethinking Criminal Law (OUP 2000).

Harrison K M, 'Law, Order, And The Consent Defense' (1993) 12 St. Louis University Public Law Review 477.

Hill T, Autonomy and Self-Respect (Cambridge University Press 1991).

Hurd H M, 'The Moral Magic of Consent' (1996) 2 Legal Theory 121.

Kamisar Y, 'Some Non-Religious Views against Proposed Mercy Killing Legislation' (1958) 42 Minnesota Law Review 969.

Keown J, Euthanasia, Ethics and Public Policy: An Argument Against Legalisation (Cambridge University Press 2002).

Leng R, 'Consent in Criminal Law' (1988) 13 Holdsworth Law Review 129.

Mill J S, On Liberty (2 $2^{\text {nd }}$ edn, J. W. Parker and Son 1859). 